\title{
Physico-chemical, functional and pasting characteristics of flour produced from Jackfruits (Artocarpus heterophyllus) seeds
}

\author{
F.C.K. Ocloo ${ }^{1 *}$, D. Bansa ${ }^{2}$, R. Boatin ${ }^{2}$, T. Adom ${ }^{2}$, W.S. Agbemavor ${ }^{1}$ \\ ${ }^{1}$ Biotechnology and Nuclear Agriculture Research Institute, Ghana Atomic Energy \\ Commission, P.O. Box LG 80, Legon, Ghana. \\ ${ }^{2}$ Radiological and Medical Science Research Institute, Ghana Atomic Energy Commission, \\ P.O. Box LG 80, Legon, Ghana. \\ Corresponding email: ocloofid@hotmail.com \\ ABSTRACT
}

\begin{abstract}
The search for lesser known and underutilized crops, many of which are potentially valuable as human and animal foods has been the focus for research in recent years. The aim of this study is to determine the physico-chemical and functional properties of jackfruit seed flour. The fruits were cut, the seeds removed, sliced, dried at $60{ }^{\circ} \mathrm{C}$ for $24 \mathrm{hrs}$, milled using hammer mill to pass through a $250 \mu \mathrm{m}$ sieve, packaged in polyethelyne bag and kept in a refrigerator $\left(\sim 4{ }^{\circ} \mathrm{C}\right)$. The moisture content of the jackfruit seed flour was $6.09 \%$. The ash and fat contents (dry matter basis) were $2.70 \%$ and $1.27 \%$ respectively. The protein content, fibre content and carbohydrate content were $13.50 \%, 3.19 \%$ and $79.34 \%$ respectively. The caloric value obtained was 382.79 $\mathrm{kcal} / 100 \mathrm{~g}$. The Jackfruit seed flour contains an appreciable value of calcium $(3087 \mathrm{mg} / \mathrm{kg})$, Iron (130.74 mg/kg), potassium (14781 mg/kg), sodium $(60.66 \mathrm{mg} / \mathrm{kg})$, copper $(10.45 \mathrm{mg} / \mathrm{kg}$ ) and manganese $(1.12 \mathrm{mg} / \mathrm{kg}$ ). The $\mathrm{pH}$ and titratable acidity values were 5.78 and $1.12 \%$ (as lactic acid) respectively. High water absorption capacity $(25 \%)$, fat absorption capacity $(17.0 \%)$ and bulk density $\left(0.80 \mathrm{~g} / \mathrm{cm}^{3}\right)$ were recorded for the jackfruit seed flour. The values for swelling power, foam capacity and foam stability were $4.77,25.34 \%$ and $33 \%$ respectively. The flour produced may be use as thickening and binding agent in food systems.
\end{abstract}

Keywords: Jackfruit seeds flour, Mineral composition, pasting profile, proximate

\section{INTRODUCTION}

The search for lesser known and underutilized crops, many of which are potentially valuable as human and animal foods has been the focus for research in recent years. Jackfruit tree (Artocapus heterophyllus) belongs to the family Moraceae. The fruit provides about $2 \mathrm{MJ}$ of energy per $\mathrm{kg}$-wet weight of ripe perianth (Ahmed et al., 1986). Jackfruit has been reported to contain high levels of protein, starch, calcium and thiamine (Burkill, 1997). The seeds may be boiled, or roasted and eaten or boiled and preserved in syrup like chestnuts. Roasted, dried seeds are ground to make flour which is blended with wheat flour for baking (Morton, 1987). The composition of jackfruit perianth and seed has been reported (Selvaraj and Pal, 1989; Bobbio et al., 1978; Rahman et al., 1995; Hossain et al., 1990 and Morton, 1987). Also few studies reported on functional properties of jackfruit flour (Odoemelon, 2005). In Ghana, no study has been conducted on the physico-chemical and functional properties of jackfruit seeds flour. This project is therefore aimed at determining the physico-chemical and functional properties of jackfruit seed flour in order to explore its potentials in food systems.

\section{METHODOLOGY}

Mature Jackfruits were harvested from $\mathrm{Ho}$ in the Volta Region of Ghana and stored at cold room temperature $\left(4^{\circ} \mathrm{C}\right)$. The fruits were cut, the seeds removed from the perianths of fruits and the outer layer removed manually. The seeds were then sliced with knife and dried at $60{ }^{\circ} \mathrm{C}$ for $24 \mathrm{hrs}$. The dried seeds were finally milled using hammer mill to pass through a $240 \mu \mathrm{m}$ sieve. The samples were then packaged in polyethylene bag and kept in a refrigerator $\left(\sim 4^{\circ} \mathrm{C}\right)$ until needed for use.

Physico-chemical Properties: The following were determined using standard methods of analysis: Moisture, AOAC method 14.004 (1990); Crude fat (AOAC, 1990), Crude ash, AOAC method 14.006, Crude protein (AOAC, 1990), Crude fibre (AOAC, 1990), pH (AOAC, 1990) and Titratable acidity (AOAC, 1990). Carbohydrate content was determined by subtracting the total crude protein, crude fibre, ash and crude fat from the total dry 
Agric. Biol. J. N. Am., 2010, 1(5): 903-908

matter. The Energy (Caloric value) estimation was done by summing the multiplied values for crude protein, fat and carbohydrate (excluding crude fibre) by their respective AT WATER factors (4, 9 and 4).

\section{Elemental composition}

Technique: Instrumental Neutron Activation Analysis (INAA) was used to determine the concentrations values of elements in Jackfruit seed flour.

Sample preparation: Jackfruit seed flour sample was thoroughly mixed to obtain uniform sample before weighing. About $200 \mathrm{mg}$ of sample was weighed in triplicates on a clean polyethylene film folded with forceps and heat sealed with a hair dryer. The sample was in turn put into rabbit capsule and smoothly heat sealed with a soldering rod. Standard Reference Material (Whole milk powder 8435) from the National Institute of Standards and Technology was equally prepared as the test sample.

Sample Irradiation and Counting: Jackfruit seed flour sample and control were irradiated in the Ghana Research Reactor (GHARR-1) at the Ghana Atomic Energy Commission, operating at $15 \mathrm{KW}$ at a thermal flux of $5 \times 10^{11} \mathrm{n} \cdot \mathrm{cm}^{-2} \cdot \mathrm{s}^{-1}$. Samples were transferred into irradiation sites via pneumatic transfer system at a pressure of $60 \mathrm{psi}$. The irradiation was categorized according to the half-life of the element of interest. For ${ }^{27} \mathrm{Mg},{ }^{49} \mathrm{Ca},{ }^{56} \mathrm{Mn}$ and ${ }^{66} \mathrm{Cu}$ samples were irradiated for two minutes and counted for ten minutes. For medium lived radionuclides like ${ }^{24} \mathrm{Na}$ and ${ }^{42} \mathrm{~K}$ samples irradiated for one hour and delayed for 24 hrs with 10 minutes counting. For long lived radionuclides samples were irradiated for $4 \mathrm{hrs}$ and delayed for two weeks with $10 \mathrm{hrs}$ counting. After, the irradiation, radioactivity measurement of the induced radionuclide was performed by a $P C$ - based $Y$ - ray spectrometry set-up. It consists of an n-type HPGe detector coupled to a computer based multi-channel analyzer (MCA) via electronic modules. The relative efficiency of detector is $25 \%$ and its energy resolution of $1.8 \mathrm{keV}$ at a $\mathrm{Y}$ - ray energy of $1332 \mathrm{keV}$ belonging to ${ }^{60} \mathrm{Co}$. Identification of $\mathrm{Y}$ - ray of product radionuclide was identified through the energies and quantitative analysis of the concentration was achieved using the $\mathrm{Y}$ - ray spectrum analysis software (ORTEC MEASTRO-32).

Pasting Profile of Jackfruit seed flour: This was determined using Brabender Viscograph-E (Brabender $\mathrm{GmbH} \&$ Co. KG, Germany). About $40 \mathrm{~g}$ moisture-free sample was suspended in $420 \mathrm{ml}$ distilled water to prepare slurry in a large beaker. Once the moisture content of the sample was fed into the windows interface of the software, the corrected weight (more than $40 \mathrm{~g}$ ) of the test sample to be weighed and the volume (less than $420 \mathrm{ml}$ ) of tap water to be measured were automatically generated. The suspension of the flour was mixed thoroughly and poured into the measuring bowl of the Brabender Viscograph-E. The test was run at a speed of seventy-five (75) revolution per minute with a measuring range of $700 \mathrm{cmg}$. The temperature profile of the analysis was programmed to commence measurement at a temperature of $50{ }^{\circ} \mathrm{C}$ with heating at the rate of $3{ }^{\circ} \mathrm{C} / \mathrm{min}$ up to a temperature of $92{ }^{\circ} \mathrm{C}$. The temperature of the sample was held constant for fifteen (15) minutes and then cooled at the rate of 3 ${ }^{\circ} \mathrm{C} / \mathrm{min}$ to a temperature of $55^{\circ} \mathrm{C}$. This temperature was also held constant for fifteen (15) minutes. The pasting characteristics were then determined by reading the following: the time, temperature and viscosity at the beginning of gelatinization, maximum viscosity, start of holding period, start of cooling period, end of cooling period, and at the end of final holding period as well as breakdown and set back viscosities.

\section{Functional Properties}

Water Absorption Capacity: This was determined using methods described by Beuchat (1977). One gram sample was weighed into $25 \mathrm{ml}$ graduated conical centrifuge tubes and about $10 \mathrm{ml}$ of water added. The suspensions were allowed to stand at room temperature $\left(30 \pm 2{ }^{\circ} \mathrm{C}\right)$ for $1 \mathrm{hr}$. The suspension was centrifuge at $200 \times \mathrm{g}(2000 \mathrm{rpm})$ for 30 minute. The volume of water on the sediment was measured and the water absorbed expressed as per cent water absorption based on the original sample weight.

Oil Absorption Capacity: This was determined using methods described by Beuchat (1977). One gram sample was weighed into $25 \mathrm{ml}$ graduated conical centrifuge tubes and about $10 \mathrm{ml}$ of refined vegetable oil (Frytol brand. Density, $0.89 \mathrm{~g} / \mathrm{ml}$ ) added. The suspension was centrifuge at $200 \times \mathrm{g}$ (2000 rpm) for 30 minute. The volume of oil on the sediment was measured and the oil absorbed expressed as per cent oil absorption based on the original sample weight.

Bulk Density: This was determined by the method of Narayana and Narasinga Rao (1984). A graduated cylinder tubes were weighed and flour sample filled to $5 \mathrm{ml}$ by constant tapping until there was no further change in volume. The contents were weighed and 
Agric. Biol. J. N. Am., 2010, 1(5): 903-908

the difference in weight determined. The bulk density was computed as grams per milliliter of the sample.

Swelling power: This was determined with the method described by Leach et. al. (1959) with modification for small samples. One gram of the sample was mixed with $10 \mathrm{ml}$ distilled water in a centrifuge tube and heated at $80{ }^{\circ} \mathrm{C}$ for $30 \mathrm{~min}$. The mixture was continually shaken during the heating period. After heating, the suspension was centrifuged at $1000 \times \mathrm{g}$ for $15 \mathrm{~min}$. The supernatant was decanted and the weight of the paste taken. The swelling power was calculated as: swelling power = weight of the paste/weight of dry sample.

Foam capacity and Foam Stability: The method described by Narayana and Narasinga Rao (1982) was used for the determination of foam capacity (FC) and foam stability (FS). Two grams of flour sample was added to $50 \mathrm{ml}$ distilled water at $30 \pm 2{ }^{\circ} \mathrm{C}$ in a $100 \mathrm{ml}$ measuring cylinder. The suspension was mixed and properly shaken to foam and the volume of the foam after $30 \mathrm{~s}$ was recorded. The FC was expressed as a percentage increase in volume. The foam volume was recorded in $1 \mathrm{hr}$ after whipping to determine the FS as a percentage of the initial foam volume.

\section{RESULTS AND DISCUSSION}

Physico-chemical Properties

Moisture: Moisture provides a measure of the water content of the seed flour and for that matter its total solid content. It is also an index of storage stability of the flour. The moisture content of the seed flour was $6.09 \%$ (Table 1). The lower the moisture content of flour, the better its shelf stability and hence the quality. Moisture contents of flour generally is depended upon the duration of the drying process.

Crude Fat: The fat content of the jackfruit seed flour was $1.27 \%$ (Table 1). This value is relatively low when compared to pearl millet $(7.6 \%)$ and quinoa (6.3\%) (Oshodi et al., 1999), pigeon pea flour (1.80\%; Okpala and Mammah, 2001) and wheat flour (3.10\%; Akubor and Badifu, 2004). Values of 32.13 and 35.43 $\%$ were reported by Oladele and Aina (2007). The result is however compared with fat content of jackfruit seeds in literature $(0.88 \%$, dry matter basis) (Morton, 1987). Singh et. al. (1991) reported lipid values of $2.2 \%$ for Jackfruit seeds. The observed value is however comparable to value reported by Bobbio et. al. (1978), who reported $1.3 \%$. Kumar et. al. (1988) also reported crude lipid content of 2.1-2.5 $\%$ for jackfruit seeds.

Crude Ash: The per cent ash content of the flour was $2.70 \%$ (Table 1). The ash content is the organic residue remaining after the organic matter has been burnt away. It is not necessarily of exactly the same composition as the mineral matter present in the original flour as there may be losses due to volatilization or some interactions between constituents. Ash content of $2.76-3.31 \%$ (dry matter basis) has been reported for jackfruit seeds (Morton, 1987). The disparity may be due to varietal differences and the locality. Oladele and Aina (2007) reported values of $3.97 \%$ and $4.25 \%$ for tiger nut flours.

Crude protein: The per cent crude protein of the flour was $13.50 \%$ (Table 1). The value obtained was however lower than that obtained by Singh et. al. (1991). The difference observed may be contributed by varietal differences, maturation of the seeds and environmental conditions. Bobbio et. al. (1978) reported value of $31.9 \%$. Kumar et. al. (1988) also reported protein content of 17.8-18.3\% for jackfruit seeds. Values of $6.34-8.57 \%$ have also been reported for jackfruit seed flour (Mukprasirt and Sajjaanantakul, 2004).

Crude fibre: The per cent crude fibre of the flour was $3.19 \%$ (Table 1). This value is comparable to value of $3.06 \%$ reported by Singh et. al. (1991). Crude fibre value of $2.36 \%$ was also reported by Tulyathan et. al. (2002). The disparity may be due to varietal differences and the locality.

Carbohydrate: The major component of the flour was carbohydrate. The value obtained from the study was $79.34 \%$ (Table 1). This result is comparable to those reported by Singh et. al., 1991 (74 \%), Kumar et. al., 1988 (76.1\%) and Tulyathan et. al., 2002 $(81.64 \%)$. However, the value obtained is higher than that reported by Bobbio et. al., 1978 (66.2 \%).

Energy: The caloric value (energy) of the Jackfruit seed flour was $382.79 \mathrm{kcal} / 100 \mathrm{~g}$ (Table 1). This value is higher than that reported by Akinmutimi (2006) for Jackfruit seed $(292-313 \mathrm{kcal} / 100 \mathrm{~g})$.

pH and Titratable acidity: The $\mathrm{pH}$ and titratable acidity (as lactic acid) of the seed flour were 5.78 and $1.12 \%$ respectively (Table 1 ). $\mathrm{pH}$ value gives a measure of the acidity or alkalinity of the flour, while the titratable acidity gives a measure of the amount of acid present in the fruit. The levels of these indices are used to estimate the quality of the flour.

Mineral composition: Table 2 shows the mineral composition of the flour. The Jackfruit seed flour prepared is rich in calcium $(3087 \mathrm{mg} / \mathrm{kg})$, magnesium (3380 $\mathrm{mg} / \mathrm{kg}$ ) and potassium (14781 $\mathrm{mg} / \mathrm{kg})$. It is 
however low in iron and copper. Akinmutimi (2006) reported values $0.4667 \%$ (phosphorus), $67 \%$ (iron), $7.05 \%$ (copper), $28.85 \%$ (manganese), $73.4 \%$ (zinc), 0.099 (calcium), $1.21 \%$ (potassium) and 0.025 $\%$ (sodium). The value obtained for potassium is comparable to that reported by Akinmutimi (2006). The differences observed could be attributed to the analytical methods used for estimation, the variety of Jackfruit and the geographical location of the plant.

Table 1: Some physico-chemical properties of Jackfruit seed flour.

\begin{tabular}{|l|l|}
\hline Indices & Values (\% dry matter) \\
\hline Moisture & $6.09 \pm 0.01$ \\
\hline Crude fat & $1.27 \pm 0.01$ \\
\hline Ash & $2.70 \pm 0.02$ \\
\hline Protein & $13.50 \pm 0.06$ \\
\hline Fibre & $3.19 \pm 0.01$ \\
\hline Carbohydrate & $79.34 \pm 0.06$ \\
\hline Energy (Kcal/100g) & $382.79 \pm 1.20$ \\
\hline pH Acidity (as, & $1.12 \pm 0.03$ \\
\hline $\begin{array}{l}\text { Titratable } \\
\text { lactic acid) }\end{array}$ & \\
\hline
\end{tabular}

Values were recorded in triplicates $(n=3)$

Table 2: Minerals composition of Jackfruit seed flour

\begin{tabular}{|l|l|}
\hline Minerals & Values $(\mathbf{m g} / \mathbf{k g})$ \\
\hline Calcium & $3087 \pm 166$ \\
\hline Magnesium & $3380 \pm 388$ \\
\hline Iron & $130.74 \pm 12.37$ \\
\hline Zinc & $<0.01$ \\
\hline Potassium & $14781 \pm 256$ \\
\hline Manganese & $1.12 \pm 0.11$ \\
\hline Copper & $10.45 \pm 0.89$ \\
\hline Sodium & $60.66 \pm 2.01$ \\
\hline
\end{tabular}

Pasting Profile: The pasting characteristics of the Jackfruit seed flour is shown in Table 3 and Fig. 1. A pasting temperature of $88.2{ }^{\circ} \mathrm{C}$ was obtained, which is slightly higher than value of $81{ }^{\circ} \mathrm{C}$ reported by Tulyanthan et. al. (2002) for Jackfruit starch. The maximum viscosity of the flour was $356 \mathrm{BU}$, which falls below value reported by Tulyanthan et. al. (2002). They reported peak viscosity value of 798 BU. This disparity is expected since flour is not a pure sample as compared to Jackfruit starch. The hot paste stability at $92{ }^{\circ} \mathrm{C}$ was $134 \mathrm{BU}$, suggesting a further breakdown of granules due to stirring. On cooling paste from $92{ }^{\circ} \mathrm{C}$ to $50^{\circ} \mathrm{C}$, there was a slight increase in the viscosity. High values reflect the ability of the elements in paste to associate as temperature of the paste decrease. From the result however, the cooled viscosity value was lower than the peak viscosity value obtained. The paste stability at $50{ }^{\circ} \mathrm{C}$ was $4 \mathrm{BU}$; this suggests that the paste is somehow resistant to shear. The low set back value of $58 \mathrm{BU}$ obtained shows that the paste has a noncohesive property. The breakdown viscosity value obtained was $186 \mathrm{BU}$, which is slightly high and may indicate instability of the paste. The pasting profile of the Jackfruit seed flour used suggests that the starch of Jackfruit seed has moderate peak viscosity with moderate process tolerance and may be susceptible to over-cooking.

Table 3: Pasting profile evaluation summary of Jackfruit seed flour

\begin{tabular}{|c|c|}
\hline Indices & Values \\
\hline Pasting temperature $\left({ }^{\circ} \mathrm{C}\right) \mathrm{A}$ & 88.2 \\
\hline Peak/Maximum viscosity (BU) B & 356 \\
\hline Viscosity @ $92{ }^{\circ} \mathrm{C}(\mathrm{BU}) \mathrm{C}$ & 304 \\
\hline Viscosity @ $92{ }^{\circ} \mathrm{C}$ after 15 min. (BU) D & 170 \\
\hline Viscosity @ $50^{\circ} \mathrm{C}(\mathrm{BU}) \mathrm{E}$ & 228 \\
\hline Viscosity @ $50{ }^{\circ} \mathrm{C}$ after 15 min. (BU) F & 224 \\
\hline Paste stability @ $92{ }^{\circ} \mathrm{C}(\mathrm{BU}) \mathrm{C}$ - D & 134 \\
\hline Paste stability @ $50^{\circ} \mathrm{C}(\mathrm{BU}) \mathrm{E}$ - F & 4 \\
\hline Breakdown (BU) & 186 \\
\hline Setback (BU) & 58 \\
\hline
\end{tabular}

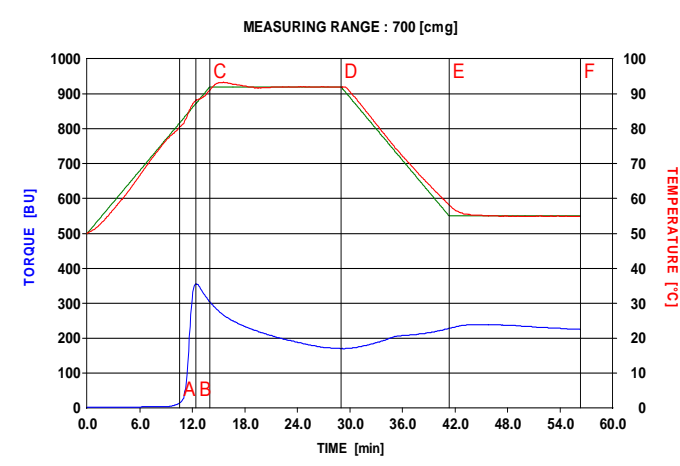

Fig. 1: Paste viscosity of Jackfruit seed flour as determined by a Brabender Visco-amylograph

\section{Functional Properties}

Water Absorption Capacity: The water absorption capacity for the Jackfruit seed flour was $25 \%(2.5$ $\mathrm{ml} / \mathrm{g}$ ) (Table 4). The value is higher than $2.3 \mathrm{ml} / \mathrm{g}$ reported for raw jackfruit flour (Odoemelam, 2005) and $1.7 \mathrm{ml} / \mathrm{g}$ reported for African yam bean (Eke and Akobundu, 1993). It is however comparable to 3.4 $\mathrm{ml} / \mathrm{g}$ reported for raw conophor flour (Odoemelam, 2003). Values of $1.26-1.37 \mathrm{ml} / \mathrm{g}$ have also been 
reported for tiger nut flours (Oladele and Aina, 2007). Water absorption capacity describes flour - water association ability under limited water supply. The result obtained however is lower than those reported by Singh et. al., 1991 (141\%) and Tulyathan et. al., 2002 (205\%) for whole jackfruit seed flour and jack fruit seeds without brown spermoderm. The disparities observed could be attributed to the method used as well as the varietal differences. The result obtained shows that the flour has a good ability to bind water. This result suggests that Jackfruit seed flour could be used in bakery industry.

Fat Absorption Capacity: The fat absorption capacity was found to be $17.0 \%(1.7 \mathrm{ml} / \mathrm{g})$ (Table 4). Fat absorption is an important property in food formulations because fats improve the flavour and mouthfeel of foods (Kinsella, 1976). The result obtained is comparable to $2.8 \mathrm{~g} / \mathrm{ml}$ reported for raw jackfruit flour (Odoemelam, 2005). Values of 1.07 $1.13 \mathrm{ml} / \mathrm{g}$ were reported for tiger nut flour (Oladele and Aina, 2007). Narayana and Narasinga Rao (1982) reported values of $1.2-1.4 \mathrm{ml} / \mathrm{g}$ for raw winged bean. Eke and Akobundu (1993) also reported value of $1.42 \mathrm{ml} / \mathrm{g}$ for African yam bean. The result obtained however is lower than those reported by Singh et. al., 1991 (90.2 \%) and Tulyathan et. al., $2002(92.6 \%)$ for whole jackfruit seed flour and jack fruit seeds without brown spermoderm. The disparities observed could be attributed to the method used as well as the varietal differences. The result obtained shows that jackfruit seed flour is a high flavour retainer and may therefore find useful application in food systems such as ground meat formulations.

Bulk density: Bulk density is depended upon the particle size of the samples. The value obtained from the study was $0.80 \mathrm{~g} / \mathrm{cm}^{3}$ (Table 4). Odoemelan (2005) also reported a bulk density value of raw flour from Jackfruit seeds to be about $0.61 \mathrm{~g} / \mathrm{ml}$. Bulk density is a measure of heaviness of a flour sample. It is important for determining packaging requirements, material handling and application in wet processing in the food industry. Oladele and Aina (2007) reported values of $0.55-0.62 \mathrm{~g} / \mathrm{cm}^{3}$ for tiger nut flours. Values of $0.54 \mathrm{~g} / \mathrm{cm}^{3}$ for African breadfruit kernel flour and $0.71 \mathrm{~g} / \mathrm{cm}^{3}$ for wheat flour have also been reported (Akubor and Badifu, 2004). The value obtained is higher than that reported in literature. Since flours with high bulk densities are used as thickeners in food products, the Jackfruit seed flour studied could be used as a thickener.

Swelling power: The result for swelling power is presented in Table 4. The Jackfruit seed flour has swelling power value of 4.77 . This value is lower than those reported for native and ginger modified starches. Values of 8.9 and 12.9 were reported by Daramola and Osanyinlusi, 2006 for native and ginger modified starches respectively. Swelling power is a measure of hydration capacity, because the determination is a weight measure of swollen starch granules and their occluded water. Food eating quality is often connected with retention of water in the swollen starch granules (Rickard et al., 1992).

Foam capacity: The foam capacity of the jack fruit seed flour is shown in Table 4. The per cent foam capacity is about $25 \%$ which is higher than values reported for pearl millet flour and quinoa flour (11.30 and $9 \%$ respectively) (Oshodi et. al. 1999). However this value is comparable to values reported for African breadfruit kernel flour and wheat flour respectively (20 and $40 \%$ ) (Akubor and Badifu, 2004). Foamability is reported to be related to the amount of solubilized protein (Narayana and Narasinga Rao, 1982; Lin et al., 1974) and the amount of polar and non-polar lipids in a sample (Nwokolo, 1985).

Foam Stability: The foam stability of the Jackfruit seed flour is represented in Table 4 . The per cent foam stability is about $33.0 \%$ which is higher than that reported for soyflour (14.6\%) and pigen pea flour (20.0 \%) (Oshodi and Ekperigin, 1989). However it is comparatively lower than 50.6 - 58.99 $\%$ reported for tiger nut flour (Oladele and Aina, 2007). Values of 60 and $80 \%$ have been reported for wheat flour and African breadfruit kernel flour (Akubor and Badifu, 2004), respectively.

Table 4: Some functional properties of Jackfruit seed flour

\begin{tabular}{|l|l|}
\hline Indices & Values \\
\hline Water Absorption Capacity (\%) & $25.00 \pm 1.67$ \\
\hline Fat Absorption Capacity (\%) & $17.00 \pm 1.37$ \\
\hline Bulk density (g/cm $\left.{ }^{3}\right)$ & $0.80 \pm 0.02$ \\
\hline Foaming Capacity (\%) & $25.34 \pm 0.02$ \\
\hline Foam Stability (\%) & $33.00 \pm 0.01$ \\
\hline Swelling Power (g/g) & $4.77 \pm 0.10$ \\
\hline
\end{tabular}

Values were recorded in triplicates $(n=3)$

CONCLUSION:

Results from the study show that jackfruit seed flour has a lot of potential in the food industry, especially its uses as thickener and binding agent in the food systems. 


\section{ACKNOWLEDGEMENT:}

We would like to offer our gratitude to the following for their technical support; Mr.Nicolas Opata, Mr. Edward C. Brown-Appiah, and Ms. Akusika Diaba, all of Ghana Atomic Energy Commission.

\section{REFERENCES}

Ahmed, K, Malek, M, Jahan, K and Salamatullah, K. (1986). Nutritive value of Food Stuff $3^{\text {rd }}$ edn Institute of Nutrition and Food Science, University of Dhaka, Bangladesh, p. $16-17$.

A.O.A.C. (1990). Official methods of analysis. 15th edn. Washington, D. C.. Association of Official Analytical Chemists.

Akinmutimi, A.H. (2006). Nutritive Value of Raw and Processed Jack Fruit Seeds (Artocarpus heterophyllus): Chemical Analysis. Agricultural Journal. Vol. 1 (4): 266 - 271.

Akubor PI, Badifu GIO (2004). Chemical composition, functional properties and baking potential of African breadfruit kernel and wheat flour blends. Int. J. Food Sci. Tech. 39: 223-229.

Bobbio, FO, El-Dash, AA, Bobbio PA and Rodrigues, LR (1978). Isolation and characterisation of the physicochemical properties of starch of jackfruit seeds (Artocarpus heterophyllus). Cereal Chem. 55: 505 - 511.

Beuchat, LR (1977). Functional and electrophoretic characteristics of succinylated peanut flour protein. J. Agric. Food Chem. 25: $258-261$.

Burkill, HM (1997). The Useful Plants of West Tropical Africa. Vol. 4, $2^{\text {nd }}$ Edn. Royal Botanic Gardens, Kew, p. $160-$ 161.

Daramola, B. and Osanyinlusi, S.A. (2006). Investigation on modification of cassava starch using active components of ginger roots (Zingiber officinale Roscoe). African Journal of Biotechnology, Vol. 5, No. 10, pp. 917-920.

Eke OS, Akobundu ENT (1993). Functional properties of African yam bean (Sphenostylis stenocarpa) seed flour as affected by processing. Food Chem. 48: 337-340.

Hossain, MK, Azizur Rahman, M, Matior Rahman, AKM and Jabbar Mian, A. (1990). Some low molecular weight compounds isolated and characterized from jackfruit (Artocarpus heterophyllus). J. Bang. Acad. Sci. 14: 49 56.

Jimoh, K. O. Olurin, T. O. and Aina J. O. (1990). Effect of drying methods on the rheological characteristics and colour of yam flours. African Journal of Biotechnology Vol. 8 (10), pp. 2325-2328.

Kinsella JE (1976). Functional properties of protein foods. Crit. Rev. Sci. Nutr. 1: 219- 229.

Kumar, S., Singh, AB., Abidi, AB., Upadhyay, RG. And Singh, A. (1988). Proximate composition of jack fruit seeds. J. Food Sci. Techno. 25: $308-309$.

Leach, HW, McCowen, LD and Schoch, TJ. (1959). Structure of the starch granules. In: Swelling and solubility patterns of various starches. Cereal Chem. 36: $534-544$.
Lin, MJY, Humbert, ES and Sosulki, FW. (1974). Certain functional properties of sunflower meal product. J. Food Sci. 39: $368-370$

Morton, J. (1987). Jackfruit (Artocarpus heterophyllus). P. 58 64. In: Fruits of warm climates. Julia F. Morton, Miami. FL.

Mukprasirt A, Sajjaanantakul K (2004). Physico-chemical properties of flour and starch from jackfruit seeds (Artocarpus heterophyllus Lam.) compared with modified starches. Int. J. Food Sci. Tech. 39: 271-276.

Narayana K and Narasinga Rao MS (1982). Functional properties of raw and heat processed winged bean flour. J. Food Sci. 47: 1534--1538.

Narayana K and Narasinga Rao MS (1984). Effect of partial proteolysis on the functional properties of winged pea (Psophocarpus tetragonolobus) flour. J. Food Sci. 49: 944 - 947.

Nwokolo, E. (1985). Nutritional quality of the seeds of the African breadfruit (Treculia Africana Decne). Trop. Sci. 27: $39-47$.

Odoemelan SA (2003). Chemical composition and functional properties of conophor nut flour (Tetracarpidium conophorum) flour. Int. J. Food Sci. Tech. 38: 729-734.

Odoemelan SA (2005). Functional Properties of raw and heat processed jackfruit (Artocarpus heterophyllus) flour. Pakistan Journal of Nutrition 4 (6): 366 - 370.

Okpala LC and Mammah EN (2001). Functional properties of raw and processed pigeonpea (Cajanus cajan) flour. Int. J. Food Sci. Nutr. 52: 343-346.

Oladele A K and Aina JO (2007). Chemical composition and functional properties of flour produced from two varieties of tigernut (Cyperusesculentus). Afr. J. Biotechnol. Vol.6 (2): 2473-2476.

Oshodi AA and Ekperigin MM (1989). Functional properties of Pigeon Pea (Cajanus cajan) flour. Food Chem. 34: 187191.

Oshodi, AA., Ogungbenle, HN., Oladimeji, MO. (1999). Chemical composition, nutritionally valuable minerals and functional properties of Benniseed, pearl millet and quinoa flours. Int. J. Food Sci. Nutr. 50: 325 - 331.

Rahman, AKMM, Huq, E, Mian, AJ and Chesson, A. (1995). Microscopic and chemical changes occurring during the ripening of two forms of Jackfruit (Artocarpus heterophyllus). Food Chem., 52: $405-410$.

Rickard JE, Blanshard JMV, Asaoka, M (1992). Effects of cultivar and growth season on the gelatinization properties of cassava (Manihot esculenta) starch J. Sci. Food Agric. (59) $53-58$.

Selvaraj, Y. and Pal, DK. (1989). Biochemical changes during ripening of jackfruit (Artocarpus heterophyllus L). J.Food Sci. Tec., 26: $304-307$.

Singh, A. Kumar, S and Singh, IS. (1991). Functional properties of jack fruit seed flour. Lebensm - Will u Technol. 24: $373-374$.

Tulyathan, V., Tananuwong, K., Songjinda, P. and Jaiboon, N. (2002). Some physicochemical properties of jackfruit (Artocarpus heterophyllus Lam) seed flour and starch. 